\title{
Existential learning: dialogues and places to be(come) in entrepreneurial Ba practice
}

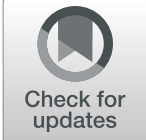

\author{
Øystein Rennemo* ${ }^{*}$ and Håvard Åsvoll
}

* Correspondence: oystein.
rennemo@nord.no
Nord University, Bodø, Norway

Springer Open

\begin{abstract}
This paper understands entrepreneurship by viewing it from the perspective of process (Van de Ven and Poole, The Academy of Management Review 20:510-540, 1995; Tsoukas and Chia, Organization Science 13:568-582, 2002; Hernes, A Process Theory of Organizing, 2014), and it contributes to the demand for process studies within the field of entrepreneurship (Hjorth et al., International Small Business Journal 33:599-611, 2015) by focusing on four entrepreneurs in situ dialogues and in places to become in entrepreneurial practice. The paper examines how entrepreneurs' existence and learning unfold from their dialogues in Ba. Emphasis is given to the emergent and relational processes through which learning and being might unfold and through which future entrepreneurial opportunities may be realised. In order to develop a theoretical register with which to articulate the dialogues and places to be(come) in entrepreneurial practice, we advance a dialogic conception of Ba based upon Nishida (Fundamental Problems of Philosophy, 1970), Nonaka (1998) and Bakhtin's (The Bakhtin Reader. Selected Writings of Bakhtin, Medvedev, Voloshinov, 1984) relational or shared perspectives. We suggest that the notions of dialogues and places to be(come) act as central drivers and conditions for meaning around which diverse entrepreneurs coalesce. Further, we argue that the dialogical and shared potential inherent in a temporary shared $\mathrm{Ba}$ or world might generate a more creative and sustainable outcome to the entrepreneurial challenges of their life projects. This paper claims the acknowledgement of the dialogue as a manifest phenomenon itself, seen through other lenses than just those of interaction, intersubjectivity and learning. Further, the paper recommends a sharper understanding of the social aspects of situated learning. Finally, the paper shows the need for more facilitation and training programmes for post-start-up entrepreneurs, highlighting the need for educators, entrepreneurial trainers, and others working in supportive functions to have a fuller understanding of what we might call lifelong learning processes situated in temporary Ba's such as the small-group learning method.
\end{abstract}

Keywords: Dialogue, Ba, l-other, Polyphony, Entrepreneurial learning, Existential

\section{Introduction}

Entrepreneurship is more than an economic phenomenon, and it can be understood from societal, geographical, cultural, and political dimensions among many others (Steyaert and Katz 2004). The interest in entrepreneurship emanates from Schumpeter's (1934) thesis on how economic development takes place as 'the carrying out of new combinations'. Schumpeter (1934) understands entrepreneurship as representing creative destruction, which refers to the incessant product and process innovation mechanism by which new

(c) The Author(s). 2019 Open Access This article is distributed under the terms of the Creative Commons Attribution 4.0 International License (http://creativecommons.org/licenses/by/4.0/), which permits unrestricted use, distribution, and reproduction in any medium, provided you give appropriate credit to the original author(s) and the source, provide a link to the Creative Commons license, and indicate if changes were made. 
production units replace out-dated ones. Generally, entrepreneurship research today defines entrepreneurs as individuals who discover, evaluate, and exploit profitable opportunities (Shane and Venkataraman 2000, p. 218). Thus, entrepreneurs as individuals often need knowledge that does not exist in a useful or tested form but instead must be created. Today, one dominant focus is on the creative aspects of entrepreneurship, in other words on how opportunities can be transformed into new companies (e.g., Shane and Sarasvathy 2000). This places the setting up of businesses in the limelight.

This paper is written from an action-oriented position (Mcmullan and Long 1987; Hills 1988; Åsvoll and Jacobsen 2012; Rennemo 2015) with the empirical ambition of giving practical help to entrepreneurs who are experimenting with new forms of learning dialogues. Therefore, entrepreneurs in general are one important target group, but not the only one. Institutions working to support entrepreneurial development are important recipients of our findings as well. In the last few decades, a considerable body of literature exploring the efficacy of organisations working to support entrepreneurs (also named Entrepreneurship Support Organisations, ESOs) has been produced. The consensus seems to be that ESOs, while helpful, are not nearly as effective and efficient as they could be in providing help to their client entrepreneurs (Sullivan 2000; Aldrich and Martinez 2001; De Faoite et al. 2003; Lichtenstein et al. 2004). A review of this literature indicates that that these organisations in general are more oriented towards service delivery than entrepreneurial development, insufficiently demand driven, insufficiently oriented towards innovation and insufficiently oriented towards learning and the production of practical knowledge. Thus another motivation for this paper is to help ESOs to search for new ways of providing better responses to client entrepreneurs' individual needs.

The aim of this paper is to understand entrepreneurship by viewing it from the process perspective (Van de Ven and Poole 1995; Tsoukas and Chia 2002; Hernes 2014). Our focus is on four entrepreneurs in in situ dialogues and places to become in entrepreneurial practice. Based on initial observations and interviews combined with initially addressed theoretical categories, the following research question emerged: How can entrepreneurs' existence and learning unfold from their dialogues in Ba? We answer this question by developing a framework of entrepreneurial dialogue that shows some important aspects of how the micro dynamics of entrepreneurial learning and existence might develop. Emphasis is given to the emergent and relational processes through which learning and being might unfold and through which future entrepreneurial opportunities might be realised. Entrepreneurship can thus be seen as a matter of entrepreneurial actors relationally 'becoming the Other'. This might happen by enabling themselves, customers and symbols to 'become the Other'. This means de-centring particular entrepreneurs-and instead centring on relational (dialogical) processes-and letting go of talk about individuals, mind operations, sense making, etc. Instead, we focus on relational processes as interactions to indicate a way into the open. This facilitates the possibility for relations to have primacy and to be 'dialogised' in entrepreneurial practices. In other words, in line with the important aspects of a process view (Tsoukas and Chia 2002; Hernes 2014), we seek to embrace process complexity by reinstating the importance of the particular $(\mathrm{Ba})$ context, (dialogical) relations, and emergence/becoming.

In order to develop a theoretical register with which to articulate the dialogues and places to be(come) in entrepreneurial practices, we advance a dialogic conception of $\mathrm{Ba}$ based upon Nishida (1970), Nonaka and Konno (1998) and Bakhtin's (1984) relational 
or shared perspectives. By conceiving meaning, being and knowledge creation as the product of social interactions between different entrepreneurs and actors, this approach recognises that dialogue is always based upon a partially shared understanding of an entrepreneurial life world. We explore this phenomenon through a case study of four entrepreneurs and their project for regenerating and developing business in Nord-Trøndelag County, Norway. Drawing upon individual-based and group-based qualitative material, we reflect upon how they talk about entrepreneurship and how this talk shapes the existential and knowledge creation practices.

The theoretical categories that are mentioned already in the title of the paper came up as a result of the process in which the stories from the four entrepreneurs started to act. In this empirical way, we want to sharpen the sensitivity to processual thinking that is needed in entrepreneurial studies (Hjorth et al. 2015) and thus be able to focus in more detail on the relational (dialogical), emergent and indeterminate status of entrepreneurial practice.

In line with social and situated learning approaches (Lave 1992; Wenger 1998), and as incorporated in entrepreneurial learning literature (Rae 2000, 2006; Hjorth and Johannisson 2009), we suggest that the notions of dialogues and places to (be)come act as central drivers and conditions for meaning around which diverse entrepreneurs coalesce. Furthermore, we argue that the dialogical and shared potential inherent in a temporary shared $\mathrm{Ba}$ or world might generate a sharper awareness to the entrepreneurial (existential) challenges of their life projects. After presenting the theoretical framework and literature review on learning, we will present the empirical analysis. Then, in the 'Discussion' section, we examine in more detail some theoretical remarks. This guides us to our final part where we give some practical implications of this study.

Writing a paper like this, we seek to update some important ethical dimensions in relation to the informants, the four women entrepreneurs. We underline that the presented stories are written on the basis of their permission. The entrepreneurs are presented with fictive names and the names of their businesses are not mentioned, nor are important business strategies or considerations mentioned. They have also had the possibility to read a draft of the paper and have accepted our use of images.

\section{Theoretical framework}

In this section, we will focus on the two general terms of 'Ba' and 'dialogue' and will lay the foundation for how they might mutually benefit each other. The concept of $\mathrm{Ba}-$ or enabling context-is currently used in the fields of information science, information systems and management/business literature. We follow its conceptual evolution, discussions, applications and expansion since its modern introduction in 1998 by Nonaka et al. (see also Nonaka and Konno 1998; Nonaka et al. 2000, 2006). Building on the concept that was originally proposed by the Japanese philosopher Kitaro Nishida (1970), we define 'Ba as a shared context in motion, in which knowledge is shared, created, and utilized ... Ba provides the energy, quality, and places to perform the individual knowledge conversions and to move along the knowledge spiral. In other words, $\mathrm{Ba}$ is a phenomenological time and space where knowledge, as a stream of meaning, emerges. New knowledge is created out of existing knowledge through the change of meanings and contexts' (Nonaka and Toyama 2015, p. 96).

It is possible to consider $\mathrm{Ba}$ as a physical space such as a meeting room, and $\mathrm{Ba}$ should be understood as a multiply interacting mechanism that explains tendencies for 
interactions that occur at any specific time and space. Ba can emerge in individuals, working groups, project teams, informal circles, temporary meetings, virtual spaces such as email groups and in the front-line contact with the customer. However, $\mathrm{Ba}$ is also an existential place where participants share their contexts and create new meanings through interactions and relations.

According to several researchers, Ba needs to be conceptualised more carefully than scholars have done so far (Creplet 2000; Augier et al. 2001; Ray and Little 2001; Fayard 2003; Nakamori 2006). Clarification requires understanding of the processes inside $\mathrm{Ba}$, and in this paper $\mathrm{Ba}$ is considered in association with a Bakhtinian dialogue, which might reveal new aspects of $\mathrm{Ba}$ and vice versa.

Bakhtin maintains that in monologue, in contrast to dialogue, a person denies that that there is any other consciousness-'another person remains wholly and merely an object of consciousness, and not another consciousness' (Bakhtin 1984, p. 293). Bakhtin writes: 'To be means to be for another, and through the other, for oneself. A person has no internal sovereign territory, he is wholly and always on the boundary; looking inside himself, he looks into the eyes of another or with the eyes of another' (Bakhtin 1984, p. 287). He continues to underline the existential and primary aspect of dialogue: 'Life by its very nature is dialogic. To live means to participate in dialogue: to ask questions, to heed, to respond, to agree, and so forth ... He invests his entire self in discourse, and this discourse enters into the dialogic fabric of human life, into the world symposium (Bakhtin 1984, p. 293).'

In Bakhtin's philosophy, dialogue or dialogism is intimately related to the concept of the 'Other' and to 'I-Other' relationships. Dialogic relationships between I and the Other (and ultimately between I and the Absolute Other) constitute the structure of Being understood as an 'event'. This fundamental ontological structure determines the forms of existence and the forms of thought, language and cultural meaning as such. For emergence of an event of being, at least two personal consciousnesses are needed, a 'co-being of being'. I and the Other are two value-centres of life that are different yet correlated with each other, and it is around these centers that all of the concrete moments of Being are distributed and arranged' (Bakhtin 1993, p. 74).

For Bakhtin, this distinction between monologue and dialogue is foundational not only for his epistemological ideas but also for his ontology and his ethics. It is 'one thing to be in relation to a dead thing, to voiceless material that can be molded and formed as one wishes, and another thing to be active in relation to someone else's living, autonomous consciousness' (Bakhtin 1984, p. 285). Bakhtin continues by describing how human awareness is formed in the context of dialogical interaction and conversation: 'I am conscious of myself and become myself only while revealing myself for another, through another, and with the help of another. The most important acts constituting self-consciousness are determined by a relationship toward another consciousness (toward a thou)' (Bakhtin 1984, p. 287).

In this paper, entrepreneurs often find themselves trapped in a conflictual pattern of interaction. Inter and intra organisational conversations might become rigid, single-voiced and closed. Bakhtin describes these conversations as monologic and proposes that true dialogue is more open, responsive and multi-voiced, where an entrepreneur is able to look at himself/herself through the eyes of another. Entrepreneurship might sometimes be a dialogised process and a dialogised image of manufacturing 
(identity). Especially at a societal level, 'discourse lives, as it were, on the boundary between its own context and another, alien context' (Bakhtin 1993, p. 284). Therefore, one would expect that entrepreneurs present contradictions that enrich heteroglossia such that a deeper dialogue of opposing voices arises out of their enterprise.

To be more specific, what does this mean in everyday life? In their discussion on dialogical relationships, Marková (1987) and Linell and Marková (1993) have argued that a truly dialogical model of everyday life is not based on two steps (from A to B and from B to A), but on three steps: step 1: A to B, step 2: B to A and step 3: new A to new B.

In step 3 of this model, $A$ is no longer the same as $A$ in step 1 but changes to some extent over the course of the dialogical process itself. The same happens to B. Ontologically argued, they both change to something new (or somebody else) as an effect of the dialogical interplay. The argument is relational, not substantial (Emirbayer 1997). Interaction and process are what are important, not the essence or the nouns. We can observe this in conversations in which people permit themselves to be influenced by the other's point of view. In the first step, person A might say: 'This is my view'. In the second step, person B responds: 'I have another way of seeing it'. In the third step, A modifies his or her initial view: 'Now I look at it in another way'.

Drawing on Marková's (1987 model, Hermans and Kempen (1993) proposed a study of the self in terms of a dialogical movement of positioning and repositioning. That is, in step 1 the person takes a position, in step 2 the voice of a real or imagined other speaks from a counter-position and, finally, step 3 represents a repositioning in that the original position of step 1 is reformulated under the influence of the intermediate step 2.

However, it makes sense to consider entrepreneurial practice from the perspective of Bakhtin and Volosinov's (1929/1994) conception of polyphony. Central to this concept is that the voice of the other is genuinely independent of the author's own voice. That is, there is genuine polyphony only if the author permits his characters to have the status of another I, standing against the claims of his own authorial view (see also Holquist 1990). It is precisely this independent status of the other that permits the author to disclose an extra-spatial realm, for which Bakhtin used the notion of 'surplus of vision'. When two people meet each other at a particular place and at a particular moment in time, they see, to some extent, a common environment (e.g. the table between them). At the same time, they see things that the other does not see (e.g. A seeing the eyes of $B$, which $B$ cannot see, and B seeing the eyes of A, which A cannot see). This aspect of the situation that the one person sees and the other does not see is what Bakhtin calls our 'surplus of vision', and he introduced this concept in order to underscore the independence of author and character as spatially and uniquely located partners in a dialogical relationship.

Polyphony builds on the idea of the utterance where the speaker and the listeners emerge as co-authors, recreating a dialogic relationship. When we speak with each other dialogically, there are already two consciousnesses involved, and there is already a combining of several voices. However, Bakhtin (1993: 272) departs from the concrete utterance in everyday life as the smallest unity in communication:

Every concrete utterance of a speaking subject serves as a point where centrifugal as well as centripetal forces are brought to bear. The processes of centralization and decentralization, of unification and disunification, intersect in the utterance; the utterance not only answers the requirements of its own language as an individualized 
embodiment of a speech act, but ... at the same time partakes of social and historical heteroglossia (the centrifugal, stratifying forces).

What Bakhtin means here is that in communication there is not only a unitary or common language, the thing we focus habitually on as necessary for understanding, and instead there is simultaneously a participation and creation of diversity through which communication and meaning escape us and yet become possible. This is the play of 'surplus', which Bakhtin (1993) relates to the 'addressivity' of an utterance. Thus we do not talk to the walls but to somebody in particular, not necessarily 'present', and who 'listens' from within certain horizons and from a specific context that can never be the same as the one speaking. Surplus emanates from this open and active listening, a kind of 'live entering' - which should not be seen as empathy-where the merging evades the space for surplus.

\section{Literature review on learning}

In this paper, we argue that a repeated learning dialogue over years between four entrepreneurs built upon trust and mutual interest in helping each other in developing each other's businesses must be regarded as an important and valuable aspect for entrepreneurial learning.

Research initiatives such as those of Cope (2005), Hamilton (2006) and Rae (2000, 2004, 2006) have brought entrepreneurial learning into the sphere of social learning by building on the social learning theory of Vygotsky (1978), the situated learning theory of Lave (1992) and the theory of learning as social practice of Lave and Wenger (1991). These studies examine entrepreneurial learning as 'contextualised,' 'situated' and 'authentic' in the everyday interactions that occur in communities of practice and in relations. Without doubt, such studies have contributed to other characteristics of the entrepreneurial learning body of literature, apparently moving away from the dominance of the cognitive paradigm and the focus on individual learning (Hamilton 2006) towards the focus on entrepreneurial learning as a social process (Rae 2000; Politis 2005) and as a dynamic form of social behaviour (Hamilton 2006). This is further developed and conceptualised through key notions-i.e. legitimate peripheral participation, day-to-day activities, community of practice learners and authentic context-that enable genuine social learning to take place in an entrepreneurial context (Rae 2000; Wenger et al. 2002).

We acknowledge the need for re-focusing research away from the emphasis on picking successful 'cognitive' and decision-making entrepreneurs to identifying key issues in the social learning and developmental process of entrepreneurship (Deakins and Freel 2010), and we like to add identifying the reality of the social dimension or what we like to call existential dialogues with borderline potential. There is a call for further research, especially for insights into the social dimensions of entrepreneurial learning, because this will expand our understanding of how learning takes place within social contexts and through social relationships (Cope 2005). More concretely, we ask not only how knowledge and understanding created in the community $(\mathrm{Ba})$ becomes the guide to action and how entrepreneurial actors can create and recreate their own community of practice (Wenger et al. 2002), but how crucial borderline dialogues and relations as they actually happen create the social or the 'embeddedness' in the entrepreneurial mind. 
Despite the prioritisation of entrepreneurship training and education over the last two decades and the explosion of entrepreneurship programmes in business schools (Page West III et al. 2009), there is still little knowledge about the enabling learning process (Gstraunthaler and Hendry 2011). To meet this challenge, a developing trend in entrepreneurship education seems to be the move away from academic pedagogical methods towards activity and action learning-oriented programmes. Several contributors have argued that entrepreneurship is best learned by the actions of the entrepreneur himself/herself in an atmosphere of trust that allows experimentation and reflection both in and on action (Mcmullan and Long 1987; Hills 1988; Åsvoll and Jacobsen 2012; Rennemo 2015).

Within the academic entrepreneurial literature, the management of unexpected and discontinuous events has been identified as a significant learning opportunity for entrepreneurs (Cope and Watts 2000; Deakins and Freel 1998; Sullivan 2000). For example, it has been demonstrated that entrepreneurs can experience distinct forms of higher-level learning when facing discontinuous events. These examples from case studies illustrate that entrepreneurs not only can experience 'double-loop' learning (Argyris and Schön 1978) but also deeply personal 'transformative' learning (Mezirow 1990, 1991) that changes their perceptions of themselves as entrepreneurs. Following Mezirow's $(1990,1991)$ assertion that crises are powerful stimulants of transformative learning, the catalyst for transformative learning can sometimes be an event that is largely self-imposed and not externally imposed as a result of a failure by the entrepreneur. In general, it seems that research suggests that some learning can become so related to the self that it enters into our sense of identity and can have considerable importance and can become a significant force in our life projects. Significant feelings can come to be attached to these types of learning experiences (Boud et al. 1985). From this 'learning event' research, it is argued that there is more to learning from discontinuous events than the incremental accumulation of more routinised, habitual, 'lower-level' learning (Cope and Watts 2000). However, the daily effort of taking many small steps, which might make a difference in entrepreneurship and innovation, should not be underestimated. This implies that one acknowledges the importance of everyday (entrepreneurial) life. As we see it, we need to recognise that the incremental entrepreneurial activity is an inherent part of everyday life and creativity, and thus the seemingly trivial activities of everyday life have great potential to move us in new and unexpected directions.

The 'higher-level' stream of research in particular illustrates that events have the capacity to stimulate distinctive forms of 'higher-level' learning that are fundamental to the entrepreneur in personal terms and with regard to critical self-reflection. It would be reasonable to say that a theorising of dialogue shares the often-neglected emphasis on critical events, self-reflection and discontinuous learning but differs with regard to a sharper focus on existential dialogical events that might exist prior to learning, (self-)reflection and personal transformation, i.e. that the entrepreneur find himself/herself experiencing polyphonic voices in a Ba world. Thus it might be important to differentiate between being/existential/dialogical events and learning. This difference will be elaborated upon in the 'Discussion' section.

There are several approaches to how (everyday) dialogue may be understood and utilised in various ways within empirical, entrepreneurially oriented research. Within an epistemological framework, the point of departure is empirical and conceptual research from numerous researchers. Leading figures of this kind of research (Steyaert 1995, 1997, 1998; Hjorth and Steyaert 2004; Steyaert and Hjorth 2003) have been 
important contributors to (epistemological) entrepreneurial research since the mid-1990s. Many other researchers have employed different approaches to promote the significance of entrepreneurial narrative, discursive and dialogic research (i.e. Mantere et al. 2013; Boutaiba 2004; Coşgel 1996; Fleming 2001; Johansson 2004; Hjorth and Johannisson 2009). Our intention here is to indicate a certain united type of research stream or trend that in various ways seems to be prevailing in parts of the entrepreneurship literature.

This is perhaps one of the reasons behind the epistemological utilisation of Bakhtinian dialogue that might eventually appear dominant. The following quotations serve to highlight and concretise how an epistemological perspective is applied by Hjorth and Johannisson (2009) and others:

"We turn to Michael Bakhtin as a dialogical thinker... Bakhtin provides us with a conceptual possibility to stay in the open (dialogue) when developing our thinking on learning" (p.64) ... From such a conceptual horizon we conceive of learning from a dialogic perspective, inspired by the writings of Bakhtin. Such a re-thinking of learning, something we consider to be a central part of our output in this chapter, we argue, allows new imaginations and offers new possibilities for entrepreneurship learners (p. 48).

This implies taking into account how,

... Vygotsky emphasises a dialogue between problems and whole situations rather than fragmented pieces presented de-contextualised. In contexts of business schools one might well argue that this dialogic style of learning is subversive (p. 28).

Hjorth and Johannisson (2009) here make the case for a new connection between (the teacher's) educational practice as dialogic teaching and the learning potential of the student as dialogue. Thus it seems that a more 'contextualised' bridge between teaching and learning is being constructed. From here, it is not a great leap to talking about pedagogical articulation and the preparation of dialogical meetings and subsequent learning. More specifically, the intention might to be improve the learning community by focusing on the following:

The possibility of learning in an active business environment from a proven performer ... ought to favor experimentation ... The fundamental ingredient in great entrepreneurship education is, as in every discipline, a passionate teacher addressing students with open minds and together working on the mutual imaginative development of knowledge: a kind of reciprocal apprenticeship (Hindle 2007, pp. 109-110, 123).

These quotations are to a large degree normative, that is, they are expressions of how entrepreneurship education (ideally) should be viewed in contrast to how it generally is (business school instruction/management thinking dominance). The process-oriented and action-based approach shared by many, such as Hjorth and Johannisson (2009), Hindle (2007), and Steyaert and Hjorth (2003), might have a considerable impact on how the learning community is designed and practiced (read more about this in Åsvoll and Jacobsen 2012, Sørheim and 
Rasmussen 2006). This is an important topic with radical implications for entrepreneurial learning and educational environments, but the main point here is the possibility of imagining dialogue in (desirable) entrepreneurial situations.

This concept of dialogue enables, among other things, a teacher to apply dialogue as a method for promoting the students' constructive and concrete-contextualised learning, where the students' active attitude and the teacher's method are considered to be highly important to accomplish 'constructive tensions and energizing friction, providing learning opportunities' (Hjorth and Johannisson 2009, p. 60). The hypothesis that it is possible to enable epistemological dialogues is further strengthened by applying more constructivist perspectives:

Socio-cultural theory...and the constructivist view of learning developed by Vygotsky (1978) and Piaget (2001) are natural starting points for pedagogical development.... The pedagogical roots of innovation pedagogy can be found in the pragmatism of John Dewey (Kettunen 2011, pp. 56-57).

In conjunction with the interpretation of dialogue as a (constructivist and constructionist) learning potential, Vygotsky (1978) in particular focuses on the social function and effect of language on individual thinking. Vygotsky's empirically oriented research with an emphasis on the potential for cognitive development of knowledge out of specific linguistic relations is based on how language transforms and mediates thought. The thesis that cultural mediation and a knowledge-developing (epistemological) dialogue might complement one another in the analyses of the empirical subject in various interactions has been accepted by a number of researchers inspired by Vygotsky, such as Bruner (1986) and Wertsch (1991). This theoretical framework has wide epistemological acceptance as well as relevance in dialogic socio-cognitive constructivistic research that focuses on how (entrepreneurship) students or empirical subjects learn better by being individuals who mediate and construct knowledge, where it is important to pay attention to experienced entrepreneurs' learning, which occurs in practice as active and reflective dialogue with peers (Hjorth and Johannisson 2009). The knowledge is achieved through the students' activity, involvement and relations and can never be a static object of learning, or as Hjorth and Johannisson (2007, p. 54) expound upon more theoretically:

This is where we might learn from Vygotsky's ideas of learning in collaboration with a 'capable peer' through which the 'zone of current development' (ZCD) can be expanded to the 'zone of proximal development' (ZPD, which becomes the new ZCD)... Bakhtin's and Vygotsky's ideas are fruitfully combined in so-called problem-based learning when the student's day can start with a writing session in which students are asked to explore their learning-to consider themselves as students of learning and not only students of entrepreneurship.

According to several authors, Ba sets the agenda for a new kind of management (Nonaka and Konno 1998; Nonaka and Takeuchi 1995), and perhaps we can talk about or set an agenda for students/entrepreneurs of $\mathrm{Ba}$. More concretely, they say that $\mathrm{Ba}$ is the place (context) in which tacit knowledge is converted and that it is the place (context) that invests the team with the ability to make creative discoveries of new products. $\mathrm{Ba}$ is considered to be a 
shared space that serves as a foundation for knowledge creation (Nonaka and Konno 1998). In an existential framework, Ba denotes the interdependence between the individual and the environment and unifies several possible spaces (physical, mental, virtual). The use of knowledge and the intellectualising capabilities within the knowledge creation process rests on $\mathrm{Ba}$ as a form of 'resource centre'. As such, Ba integrates applied knowledge and serves as a condition for self-transcendence, which enables the conversion from tacit to explicit knowledge. Through direct encounters between individuals, it is possible to share experiences, mental models, and emotions (Nonaka and Konno 1998). In short, this might be characterised as an epistemological view emphasising dialogue as a tool or technique to convert (tacit) knowledge from specialists into explicit forms that are easy to understand. It seems like $\mathrm{Ba}$ at long last must be created (on different Ba levels such as originating-, interacting-, cyber- and exercising $\mathrm{Ba}$ ), analysed and evaluated in epistemological terms.

To summarise, this seems to be one important way of entering a process-sensitive conceptualisation of entrepreneurial action that Steyaert (1995) and Gartner (1993) both call for (Gartner et al. 1992), thus both lower and higher-level learning, dialogues, and Ba might be important.

\section{Methodical considerations}

The empirical work with this paper took an action-oriented position (Mcmullan and Long 1987; Hills 1988; Åsvoll and Jacobsen 2012; Rennemo 2015) because we wanted to give practical help (finding new actions) to the involved four entrepreneurs based upon their own experiences and questions. This position was anchored in Action Learning traditions (Marsick 2002; O'Neil and Marsick 2005). The learning and reflection days (steps II and III, Fig. 1) that we the researchers arranged and designed gave us data that enabled us to extract and explore our research question about the entrepreneurs' dialogues in Ba. From that point, this study also switched to a case study, still while the entrepreneurs had the possibility to learn, reflect and act according to the action learning process. In case studies, there are challenges regarding the determination of boundaries or the unit of analysis (Creswell 1998; Stake 1995). In this study, the boundaries were defined according to individual interviews (step I, Fig. 1) with four entrepreneurs and two temporary Bas lasting approximately $5 \mathrm{~h}$ each (step II and III). As such, we approached the empirical case with no firm a priori theoretical categories.

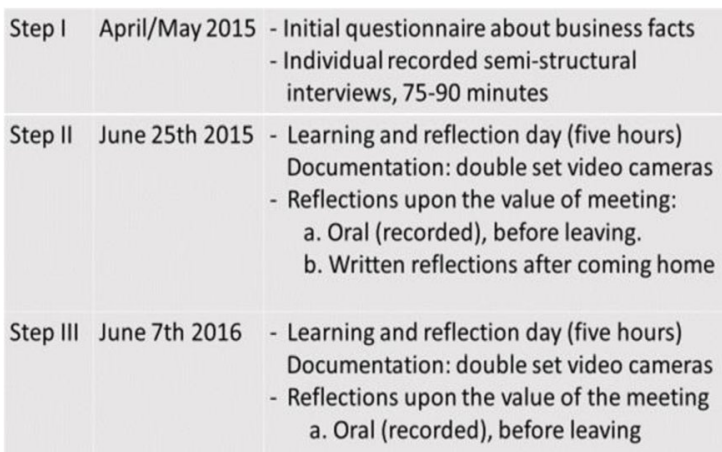

Fig. 1 Overview of the data collection 
At the initial stage of the research process (step 1), we followed the pragmatists' perspective (Peirce 1986) using an abductive approach (Dubois and Gadde 2002; Bryman and Bell 2015) in relation to our empirical field, to the stories presented by the entrepreneurs, and to the observations made when the entrepreneurs were interacting. This approach allows for deciding what the most likely inference is that can be made from a set of data. Hence, several 'inductive' and concrete themes emerged as potentially interesting data (i.e. entrepreneurial challenges regarding potential partners, further firm growth, inter-institutional cooperation, financial risks, family issues, etc.). However, when we raised the level of abstraction in order to find aggregated theoretical dimensions that could answer our questions about what was actually going on in the meeting between the entrepreneurs, we landed on the dialogue and $\mathrm{Ba}$ as the most interesting categories that were related to our research question. Especially from step 2 (see Fig. 1), we were also guided by 'deductive' terms in the research question (also formulated with theoretical terms in step 2) such as learning (epistemological dialogue) and existence (ontological dialogue) in order to reduce the data complexity and to elaborate further on the empirical analysis.

After the data collection, the boundaries were eventually set within possible combinations and elaborations of the two terms 'Ba' and 'dialogue' (i.e. categories such as learning and existence). The rationale was to rely on these potential categories, i.e. how these concepts are interpreted and combined, and then to analyse the data based on these categories (Stake 1995). The case study is thus used to provide tentative insights into how these concepts are used and combined. This involves data triangulation, i.e. choosing descriptions from various sources of research. The use of different research sources, including in-depth interviews, focus-group (video) interviews, document analysis, reflection notes and personal communication, has been shown to be a good approach (Stake 1995) to finding information, descriptions and interpretations of the entrepreneurial practice.

In this study, data were collected in three steps, according to Fig. 1, where steps 2 and 3 deserve further considerations.

The learning and reflection days (steps II and III) were recorded by two set of cameras, giving good possibilities to observe the communication and body language from each of the participants, as shown in the pictures below.

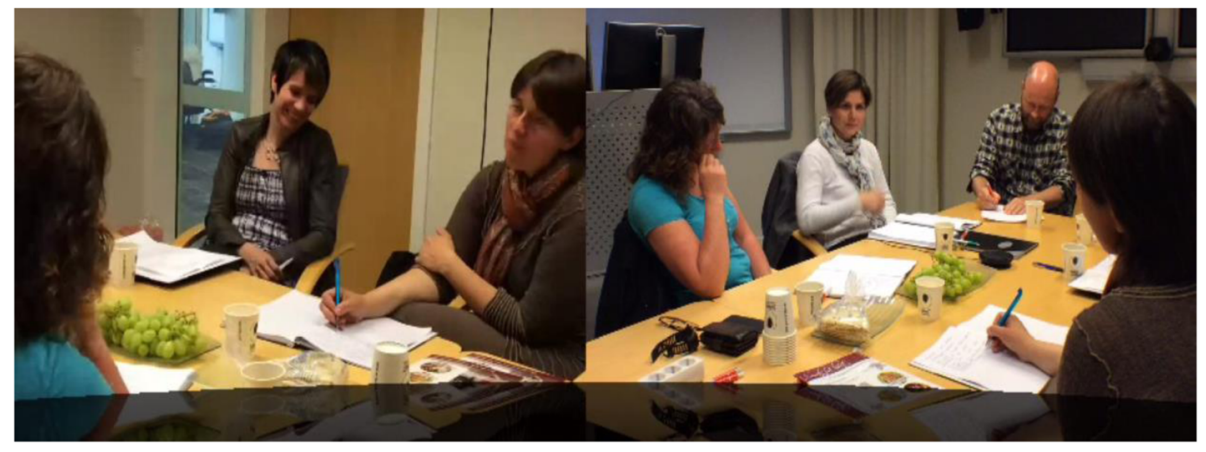

One of the cameras was set to point sideways, recording the participants' bodies and the working space of the table (sometimes covered with symbols) within a horizontal perspective (left picture), while the other was also placed sideways in order to capture the rest of the participants' upper bodies (right picture). All participants were thus 
simultaneously considered with 'two angles' of upper body videos, and this produced video recordings avoiding focusing too narrowly on only one participant (for example, the established speaker). It also took into consideration not only the recipients' (dialogical) listening, reactions, talking and actions but also the artefacts and tools manipulated by the participants (including the researchers) and their dynamic movements. This method of using two cameras is a way of monitoring not only the on-going action, but all possible participants attending to it, and it produces a strong sense of the complexity of the interactional Ba space.

Devices for preserving the continuity of space and participation framework, as well as the complexity of objects, not only concern camera focus but also subsequent transformations of the video recordings, and in this sense multi-scope videos (using split screen or picture-in-picture) constitute a technical solution (which was adopted during post-production of the data), especially for complex spaces of action (see the next section on empirical data and analysis). The video recording aims at documenting multimodal resources (language, gaze, gesture, body displays, facial expressions, etc.) as they are locally mobilised and attended to by participants. This means that the relevance of details is endogenously produced, and these details show themselves within courses of collective action because they are interactively and reflexively constructed within the contingent unfolding of Ba practice. Video records aim to make available the ways in which participants themselves deal with these details.

\section{Results}

The background to this study was a development and networking programme called Women and Growth that involved 24. Scandinavian female entrepreneurs from 2011 to 2013 (Von Friedrichs and Rennemo 2013). One of the researchers was part of this programme and thus had a relationship with the entrepreneurs. When we wanted to obtain appropriate data for our study, we asked four Norwegian entrepreneurs from this group to take part in our research. This was based on our assumption that this would be a group where some basic trust between the entrepreneurs had already been established, and this is likely why we had no problems in getting acceptance from the four women to participate. Each of the participants had a business that was more than 5 years old, they owned at least $50 \%$ of their business and they generated their main source of income from their business. Despite this, we wanted the group of entrepreneurs to represent different business sectors, without any competition between them. Below, these women are referred to by fictive names. Anna was an audiometrist, selling hearing aids and consultancy to the hearing impaired, and she ran five small clinics. Brenda's business was also in health care, but oriented towards rehabilitation of the long-term unemployed who often have some kind of mental or physical disease. Cathrine was the manager and owner of an accounting office, and Deborah ran a veterinary clinic.

The first step in the data collection (Fig. 1) was a recorded semi-structured interview with each of the four entrepreneurs lasting for approximately 75-90 min each and with participation from both researchers. Before the interview, the entrepreneurs were presented with a questionnaire where we asked about some facts about their businesses, the development history from start up until now, their own role and competence, their strategies, plans and hopes for the future, and external factors important for their 
businesses. The researchers and interviewers attempted not to bring any new ideas or proposals into the conversation. When asking questions, these were strictly follow-up questions where we for instance asked for clarifications and exemplifications. Overall, these four individual interviews did not seem to evoke many genuine dialogues, that is to say, dialogues and polyphony that build upon the idea of the utterance where the speaker and listeners emerge as co-authors in recreating a dialogic relationship (Bakhtin 1993). We analysed and listened to the data carefully, and they can best be described as monologues. The only dialogues in progress were the dialogues the entrepreneurs had with themselves, a sort of I-me dialogue with the help of follow-up questions from the researchers. These I-me dialogues, which mobilised very little friction in the conversation (or to I-Other relations), probably had the effect of strengthening the positions the entrepreneurs had taken regarding certain problems before the question was raised. Below, we have quoted a part of the interview with Anna the audiometrist, and this serves as a typical example of this sort of communication. Here she is telling about the planning of her first franchise clinic:

Anna: One of my employees, an audiometrist, was going to stop working in one of my clinics. Due to family reasons, she moved to... (her hometown). Because there are few appropriate jobs for her there, she wanted to establish a clinic under the logo of my company. Therefore, we are going to make a franchise model, and then we will see how it develops.

\section{Us: This will be your first franchise clinic?}

Anna: Yes, and then there are some questions to be considered. What will be the franchise fee? How much rent for the logo? How much to pay for internal systems and access to databases. And what per cent of her sales will go back to my company?

Us: Have you finalised your answers?

Anna: In the first place, this will give us some extra income. Maybe it would be natural to charge her $X$ thousand (Norwegian kroner) in her start-up period. Then she might take advantage of my competencies, for instance, in writing business plans and establishing important networks. We also need to find out which business systems she needs access to, SharePoint and Mamut for instance, and what the monthly charge for this should be. Finally, there will be some percentages on the sales. Then she will have a clinic under the name of my company in her hometown, but she will own it 100\% herself. I do not think it should be too easy to come to my company asking for help, and that is why these services should be paid for. On the other hand, if my company runs into problems, her company will be safe.

Maybe because there was minimal friction within the I-Other relation, there was less potential for dialogue. The purpose of the individual interviews was first and foremost to gather information, experiences and data from the entrepreneurial practices, thus perhaps the need for dialogical moments was underestimated. It might also be that dialogical relations and polyphony arise more naturally when these entrepreneurs are located together, i.e. 
when they understand that their counterparts are other entrepreneurs and not just researchers.

The next step (step II, Fig. 1) was a learning and reflection day on 25 June 2015, where all four entrepreneurs participated in a 5-h meeting, interrupted by a 30-min lunch. The programme for the day was designed by the two researchers.

We started with a check-in among the four of them because they had not met since the last meeting as part of the development and networking programme 2 years earlier. Then we presented the plan for the day, which included storytelling from each of them accompanied by free reflections from the rest of the group. We also had some summaries from each entrepreneur where they told about reactions and ideas they got from the group regarding their business and their role as managers. This was a situation where the entrepreneurs had the possibility to be involved in I-Other relations with the help of their colleagues, a more or less pure social communication situation. The material from these exercises was very convincing and told us that a lot of fundamental learning about how to develop their companies took place. In addition, some existential-related questions or insights seemed to emerge from the social I-Other relational communication. We present below some quotations related to both leadership strategy and existence:

\section{Leadership strategy}

Anna: Deborah is telling about trust in her company, related to the situation when employees want to leave and start for themselves. This is probably going to happen a lot in our business sector as well. I have realised that I need to work with this scenario. I can see many challenges (she then mentions several).

Cathrine: From your responses and feedback to my story, I can see quite clearly that I need to be much more focused upon strategic leadership and leadership issues because I am the only person in the company that is able to address them.

Deborah: Your idea about using a regular day for marketing activities, and involving a group of my employees in this, is something I want to try. I think this is a good idea for us. (As a response to this, Anna comments and gives further advice about how to make plans for marketing activities and how to delegate and follow up. Deborah takes notes while Anna is speaking.)

Brenda: I realise that I need to focus more on project development and to delegate the responsibility of handling them to some of my employees. My challenge is related to Deborah's and her marketing activities. I need to find a structure for this and protect myself from the operational level.

\section{Existence}

Brenda: I am listening to your stories about responsibility. You all feel so responsible! There is so much upon your shoulders, and I am thinking that maybe this is the way it 
is... This is what being an entrepreneur is about. Still, how much am I willing to fight to maintain the jobs we offer?

Cathrine: Sitting here today, I realise that I probably would not have survived if I had not had the network that was established between us and the other women three years ago. Now sitting here today, I have the same feeling.

Deborah: I would like to get more out of the network we have established and us four sitting here as well. I think we could gain more from this network.

Cathrine: My biggest challenge as a person is related to your reflections about me; I am a break block and need to be $150 \%$ sure before I take necessary steps. I need to be better at taking action. I need to work on this issue, and it is not only related to my job, it is all over. I see this in my private life as well.

Here, the entrepreneurs indicated how they modify their existential positioning, i.e. 'looked at it in another way', or in Bakhtinian terms permitted another 'I' (polyphony) to enter their entrepreneurial being. Utterances like 'I realise that I need to focus more on project development and delegate the responsibility (Brenda)' and 'I need to be better in taking action (Cathrine)' might exemplify what Linell and Marková (1993) call a new 'A' created in Ba. Perhaps such utterances indicate how new 'A's show up in this network Ba.

After lunch on the same day, we did another exercise, a more socio-material one so to speak. Here, each of the entrepreneurs was asked to pick a picture from a pack of cards containing 100 pictures. The exercise was developed by Management in Lund, a Swedish leadership consultancy (https:/www.milinstitute.se) as a tool for reflection. When picking up a card, we asked the entrepreneurs to search for one that spoke to them and told them something about their business and how they wanted it to develop over the next 5 years. As researchers, we wanted to find out if it was possible to become the Other through a projection task like this. After picking the picture, they all were asked to tell their story related to the picture. Below, we present some of our empirical findings.

Anna was the first person to start her presentation. She picked a picture showing three women participating in some kind of a party:

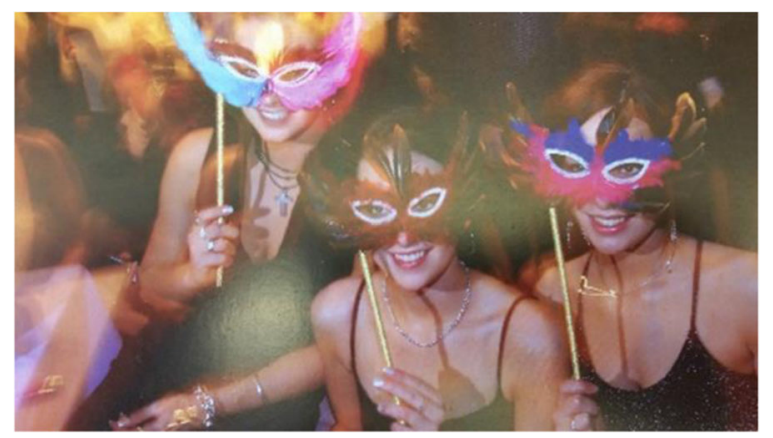

When she showed the rest of the group her picture, she said: 'This picture is illustrating a situation of having comfortable, cosy fun together. Moreover, I can see that there has been too little energy and fun in my company over the past two years'. 
Deborah was the next to pick, and she picked two pictures and told something about both of them.

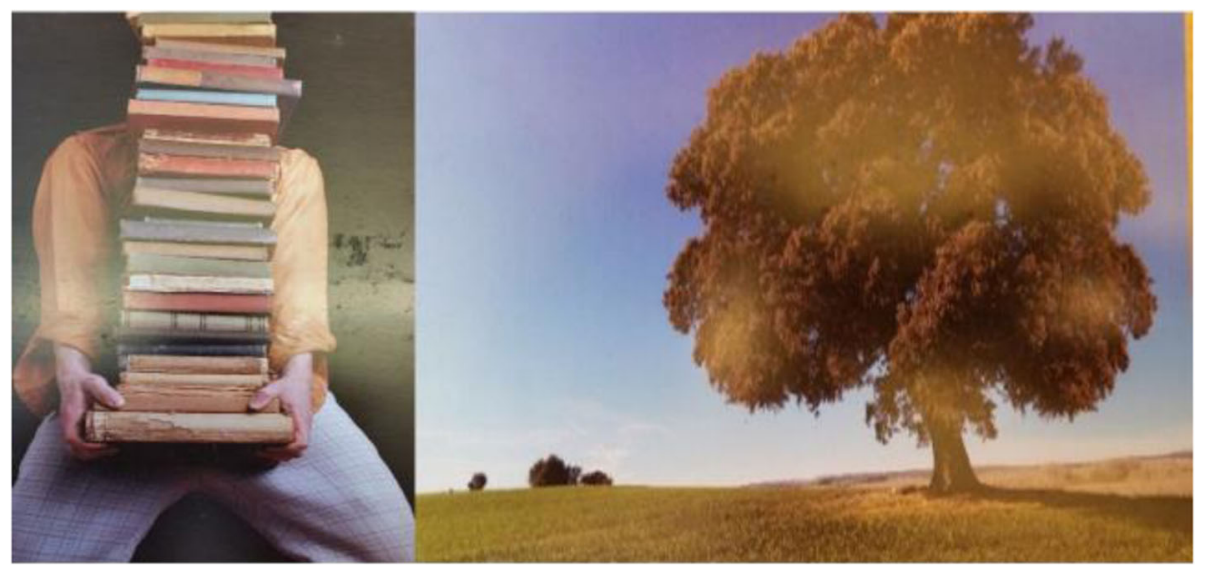

In this sequence, Deborah said: 'I feel like this now. The picture shows that I am bearing a heavy burden. Now I feel exactly like this, but I do not want the situation to continue. Within five years, I hope there will only be five books to carry. Now, I do not feel my head above water. The tree is symbolising growth, both in terms of disciplinarity, required staffing, economics, and with regard to necessary equipment-it grows. With regard to myself, green is also a very stress-reducing colour. I think I need this tranquillity, the grounding and anchoring that a tree offers. It symbolises security regarding the decisions you have to make and that it is here you want to be. There is a lot of energy in everything green and everything growing and then I think; this is what I want'. Below are images from when Deborah related this to the group.

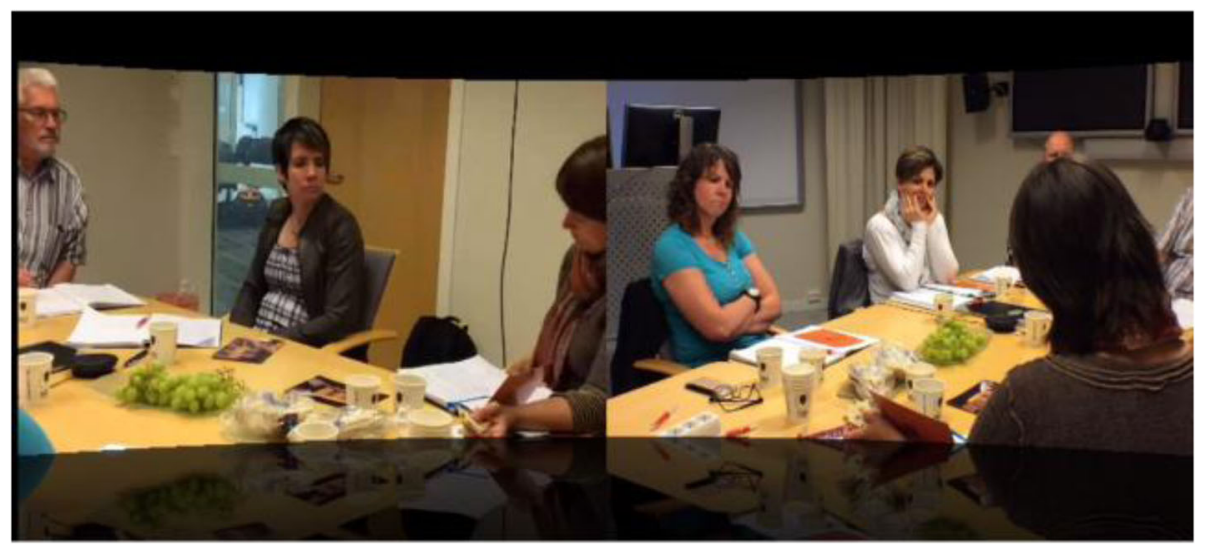

As we can see, she is talking to the picture and the other three entrepreneurs are listening to her, looking at her, confirming her story.

Then it was Cathrine's turn. She picked a picture illustrating a mountain climber.

The first thing I thought about when I saw this mountain climber was about my own situation within five years. When I look at the picture, I think that if the right buyer 
appears, then maybe I will sell my company. I also think, all the time, that it is not far to the top of the mountain. This is a mountain climber; I am doing some diving in my spare time. Within five years, I hope to spend some more time doing recreational activities.

As seen in the situational picture below, when the entrepreneur in the blue T-shirt spoke, she was looking at the picture, becoming the Other. The picture and the entrepreneur became integrated into something new, a new 'I', and the rest of the group was looking on with acceptance and confirming her story. This was, for instance, done by nodding, as the record of the whole sequence shows.

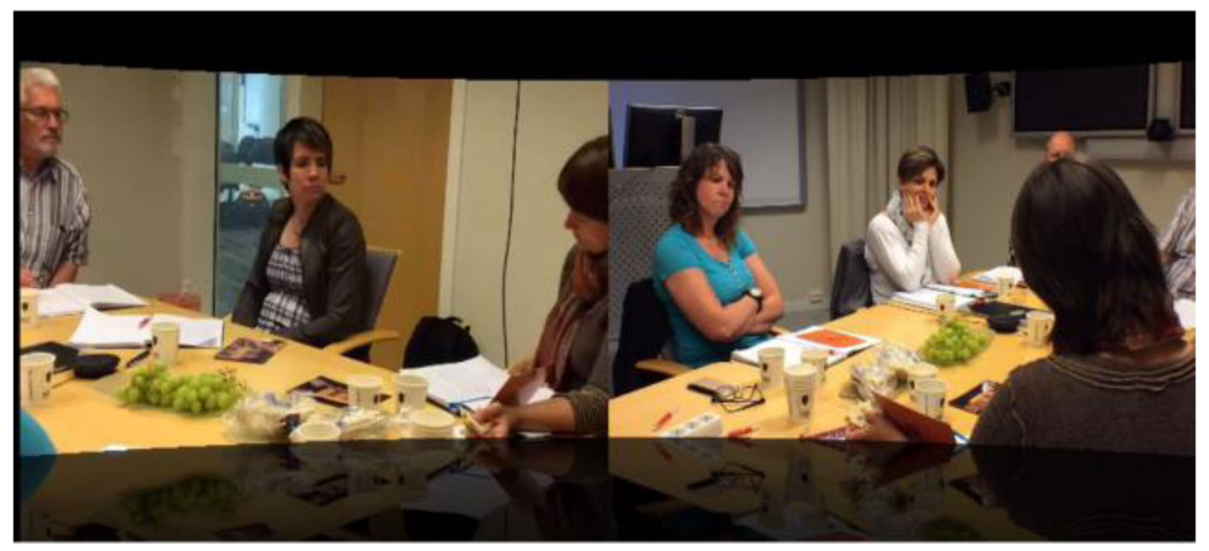

The last person to present her story was Brenda. She picked a picture illustrating drops falling into the water. 'The picture tells about our work and that we are working within a special field where we are quite fair compared to others. However, our challenge or my challenge is that our customers or those who buy our services on behalf of our customers are changing. They are not the same as they were before. We need to communicate and spread information about ourselves, and more of my employees have to take part in this information activity so that more drops will create stronger rings in the water. Today, too much of this is tied to me'.

The I-Other relation presents itself in many versions (Bakhtin 1993). Here, we have seen some dialogical I-Other relations or more concrete relations between every single entrepreneur and the symbols, and perhaps even the relations between the entrepreneurs. That is to say, the rest of the group seemed to confirm (mostly by body language) how symbols are interpreted and understood by each entrepreneur in action (looking and talking at symbols). This is not only 'looking and talking', but may also be understood as I (the entrepreneur) becoming the Other (symbol/picture) in a dialogue that articulates and transcends the entrepreneurial (self)-understanding. For example, the symbolism of mountain climbing (on the way to the top) and droplets (the need for new networks and customers) anticipates the future entrepreneurial practice and self-understanding. However, the $\mathrm{Ba}$ as an entrepreneurial setting of sharing and interpreting pictures/symbols seems to set forth the ambition to live out an ideology of dialogical relations and of everybody getting a voice and sharing their voice with each other in the process and, consequently, a view of Ba living on the plane of a polyphonic dialogue (Bakhtin 1993). 
The final part of step II in the data production was the collection of reflections and evaluations of the activities offered by the researchers, especially the learning reflection about the value of the meeting on 25 June 2015.

First, we gave the entrepreneurs the possibility to give a verbal reflection immediately before leaving the meeting. This is what they said:

Anna: We need to take a picture and place it on our Facebook page (a site including all 24 entrepreneurs who participated in Women and Growth).

Cathrine: It was really fun and inspiring meeting you once again. It is good to see that all of you are doing well.

Deborah: Today it was a great advantage to know each other so well from before.

Brenda: It is important that somebody is focusing on our situation. Entrepreneurs in the start-up period need some type of help. What I am into right now is something quite different. It is much more demanding. People in the start-up phase are given much help. Even so, a lot of them fail later. The challenges are changing, and they appear in different arenas after some time has passed.

Cathrine: And I can more easily see this after a day like this. I have my own limitations and am making mistakes and taking steps that I should not have taken. This is true of all of us.

Benda: Mmm, no trees grow and grow.

Deborah: At the same time, it is so exciting to listen to you and hear about everything you have achieved. So much has happened to all of us. You have taken so many steps forward.

Anna: But the steps are not so visible when we are sitting thinking all alone.

Deborah: You are quite right, still it is inspiring for the others to see what others achieve and then you think, maybe I have achieved something important myself.

Ba as polyphony makes it possible to understand entrepreneurship as a place and space where many voices are heard, expressing various ideas, suggestions, symbols, and stories of the entrepreneurial practice. This place and the immediate 'evaluation' of it seem to make entrepreneurship polyphonic ( Bakhtin 1993), with different voices being spoken simultaneously and as a result affecting each other in various dialogical ways (i.e. 'the steps are not so visible when we are sitting thinking all alone'). Each entrepreneur is sometimes placed on the (existential) boundary of what it is possible to say, think, and do. This opens the path for different images, ideas and interpretations of symbols/pictures. In other words, the entrepreneurial world is voiced through otherness, making the entrepreneurial practice constructive and new in a sense that when entrepreneurs look into the Other they discover themselves again through the Other, 
i.e. becoming the Other. The written evaluation conducted some days after the $\mathrm{Ba}$ meeting seemed to come to the same conclusion, that the importance and presence of the Other (entrepreneurs, symbols) makes a difference in entrepreneurial practice. In fact, all of them would like to participate in such Ba practice in the future if someone Other could be a facilitator.

Finally, in step II, we the researchers sent a prepared written questionnaire to the four entrepreneurs by mail for reflection after they returned home. They were asked to respond within a short time. One of them answered within a couple of days, another answered 1 or 2 weeks later and the last two responded after the summertime 2 months later after receiving a reminder. The contents of the evaluations were very much alike from all four participants. They were very positive to the set-up, and they wanted to take part in more of the same if given the possibility. Two of them would prefer meeting more than twice a year, while the other two suggested a meeting once a year. They all emphasised the necessity of knowing each other from before and they all wanted to continue, if possible, with the same group. Two of them were explicit when declaring that they felt satisfaction in helping others in the same situation as themselves. It is also important to mention that all of them emphasised the importance of having somebody other than themselves to arrange workshops like this and to take responsibility as facilitators.

Data from step III (Fig. 1) were collected at a learning and reflections day on 7 June 2016, almost 1 year after our previous meeting. Unfortunately, Brenda was not able to participate at this meeting due to some business problems that had come up the day before. She said she regretted this in an email to the other entrepreneurs and the researchers. The schedule for the day was much the same as for the meeting in 2015. We started with a reflection from each of the entrepreneurs where they briefly told about what had happened since the last meeting and the impact the last meeting had had on their business behaviour. They all emphasised the value of the meeting the previous year. Then the entrepreneurs were challenged to pick up the pictures they had chosen at the previous meeting. We, the researchers, wanted to see if they remembered this. All of them did. Then each entrepreneur raised some business or leadership challenges they wanted to talk about and get comments from the others about. The comments, reactions and advice came from the other two as a reflective team. After lunchtime, each of the entrepreneurs was asked to prepare an answer to the following question: If I was the leader of the other two companies, which new strategies or actions would be relevant for me to explore? Then it was time for the entrepreneurs to pick up ideas they had gotten from the others and to present and evaluate these ideas. This was followed by a sequence where the entrepreneurs once again were asked to pick up a picture from the same pack of cards as they did last time. The picture should tell something about where they wanted to be within a reasonable timeframe. This time they all picked new and different pictures than they did last year. Finally, before leaving, the entrepreneurs wrote some reflections and evaluated the day. The evaluations were in line with the pattern from the year before; they were all very positive about the outcome of the day and they wanted to meet again with the same design with the help of the researchers.

We will here give space to one of the entrepreneurial stories, as told by Deborah. Her narratives and reflections contributed to answering the research question in an 
illustrative way. When she told about her actual situation, she became very sad and at one point in her presentation tears filled her eyes:

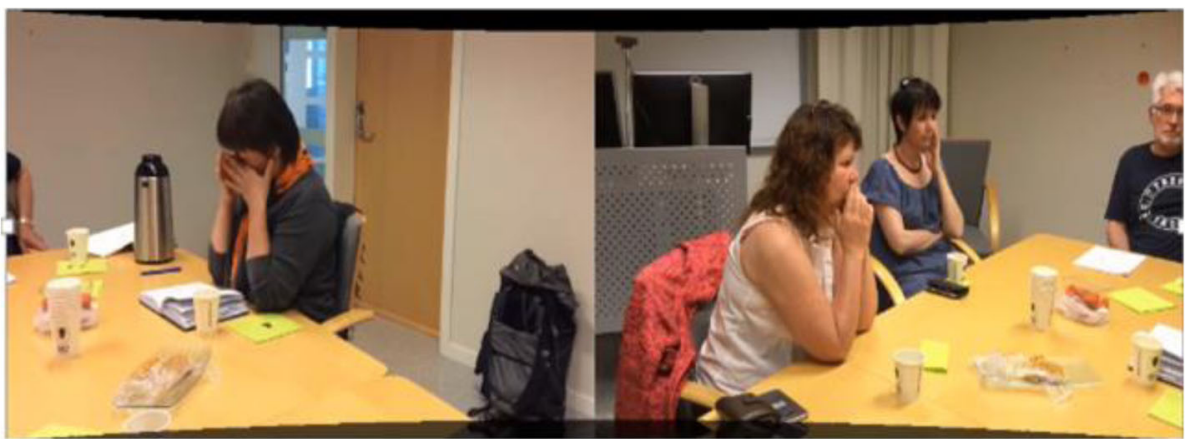

The actual business situation she talked about is not relevant for our analytical point. Her conclusions were: This is the way my life has been for the last months and it makes me so tired! In addition, I have been away from my family too much. I cannot remember the last time I helped my children with their schoolwork. From the other camera position (picture to the right), we can see that the other people in the room are listening, sharing and confirming Deborah's story. Her feelings of despair are mirrored in their body language.

At the end of the day about $4 \mathrm{~h}$ later, after all the exercises, reflections and comments, her situation had changed quite remarkably as we can see from the two pictures below. They are cut from the camera shot within the same minute. Here she comments upon the same business situation that caused such frustration earlier in the day: This is the way it has to be done. I hope everything is solved within a short period-and oh, it will be so good!

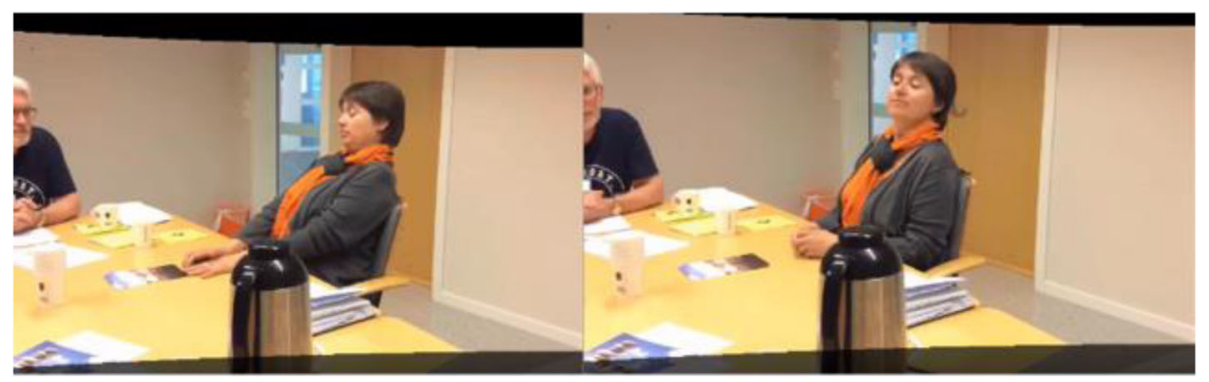

As we can see in the left picture above, Deborah looks at her picture when she speaks. The picture is illustrating a young girl in water as we can see below.

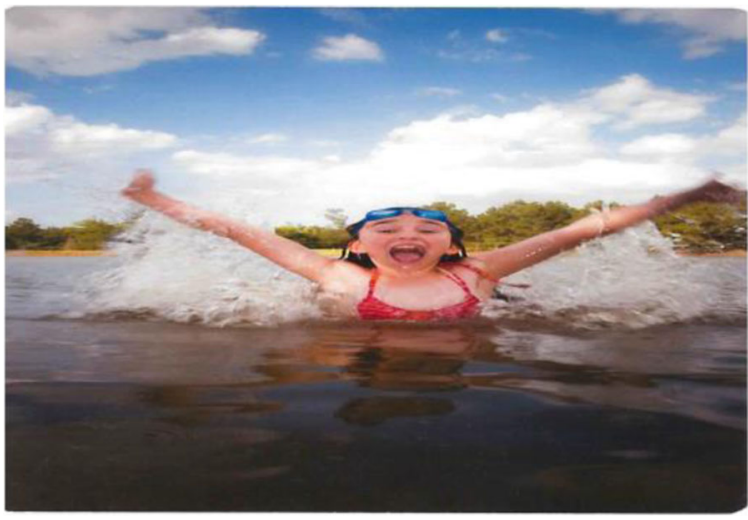


When Deborah presents the picture, she tells about parallels to her own situation and how the picture symbolises her future hopes and expectations. One of the researcher then asks: Is this girl you or your daughter? It is me, she answers. Are you going down into the water or coming up, the researcher continues. I am definitely coming up, Deborah says.

Before leaving each other, Deborah also reflected upon and evaluated the day. Her written reflections are summed up in the bullet points below:

1. Related to my situation, I got concrete and constructive help from the others.

2. There is a lot of trust in the group. Constructive reflections and a lot of help.

3. The use of pictures is really helpful.

4. The group has lot of competencies, and it is good to share common challenges.

5. Thank you for a very helpful day!

\section{Discussion}

Points of departure for this section are to explore the social dimensions of learning, facilitation and training; the 'energy' of $\mathrm{Ba}$; and the difference between (epistemological) becoming and (ontological) dialogue. Even though these are separate analytical points, they are intertwined and should be considered more like a process of wayfinding rather than independent analytical points. Importantly, this section reflects such a wayfinding perspective.

This paper explores the Ba 'learning' process within the entrepreneurial business by drawing on the video and interviews of those involved and active in the business. Effective communication among the four entrepreneurs plays a critical role in fostering mutual engagement in the business. This involvement leads to a joint enterprise (shared understanding) and a 'here and now' shared repertoire (a potential for the production of new resources), which are the main indicators of a community of practice (Lave and Wenger 1991; Wenger 1998). The participation in the community of practice or in the Ba practice develops a sense of dialogical borderline/awareness of the business, enabling them not only to (decide to) run (or not) a certain type of business and to identify and capitalise on opportunities (entrepreneurial learning) but also to make the 'capitalise' and to dwell on a polyphonic dialogue with the potential of transforming themselves. In other words, a community of practice approach (Rae 2000) emphasises a contextual occurrence, which means that the goings on between the participants must be understood as 'distributed cognition' (Lave and Wenger 1991). This research explores the social dimensions of dialogue in order to gain a 'richer picture' of the learning or the possibility of entrepreneurial learning. This possibility of dialogical learning is not necessarily something cognitive in terms of being either distributed or individual-centred, but might involve 'situated or social' borderline-Being. Consequently, dialogical learning has different social aspects depending on the analytical perspective chosen (i.e. whether it is distributed cognition or ontological dialogue), and this enables research to be performed without throwing the baby (the crucial social dimension) out with the bathwater.

Within entrepreneurship research, it is claimed that there are differences between being an entrepreneur and being a small business leader. Being an entrepreneur is often 
associated with creativity and innovation, and as the opposite to a way of doing business for the main reason of having a daily income (Bjerke 2005). The women in our study all belong to the latter group. They had all passed the start-up phase and were looking for possibilities for their business to grow. Today, at least in Scandinavia, there is far more emphasis in both research and support for start-ups, while programmes helping entrepreneurs to secure a lifelong income and further growth are less represented (Von Friedrichs and Rennemo 2013). Most entrepreneurial companies remain small in quantitative terms (Daunfeldt et al. 2011), and the number of entrepreneurial companies is maintained at a certain level because other newcomers replace a large group of former companies. Still, it is the newcomers that attract attention, not the reason for failure or unsuccessful growth among already established companies (Dalborg 2013; Dobbs and Hamilton 2007). Our study clearly shows the need for more facilitation and training programmes for post-start-up entrepreneurs if we listen to the entrepreneurs themselves. We highlight the need for educators and entrepreneurial trainers to have a fuller understanding of what we might call lifelong learning processes situated in temporary Bas such as small-group learning methods, project teams, peer exchanges and workshops.

$\mathrm{Ba}$, as a fruitful theoretical category, came up during the empirical process and was extracted because of our observation in step II (see Fig. 1). When moving from step I (individual interviews) into a meeting (room) where stories were shared among entrepreneurs who had relations to each other from before, the dialogues and learning changed ontologically. According to Ba definitions (Nishida 1970; Nonaka 1998), knowledge was shared, created and utilised. This Ba was not a fixed point in time and space, but a context in motion, ready to find its place whenever the entrepreneurs met in a qualified atmosphere and with the help of facilitators. Then the Ba provided energy and allowed each entrepreneur to move along the knowledge spiral that was important for their business development. As such, $\mathrm{Ba}$ is a phenomenological time and space where knowledge, as a stream of meaning, emerges. In addition to the freedom of every event that this temporal Ba was said to make space for, a Ba stage also opens up for a possible rebellion, outgoing frustrations, hostile comments, cynical distance, etc. That is to say, monological speech might dominate. Thus, as the Ba proceeded, the entrepreneurs sometimes recalled their ambitions and frustrations after establishing their companies; but moving together and addressing common challenges and issues perhaps provided events for the entrepreneurial voices to arise, i.e. common challenges such as working with companies/institutions on long-term projects and stakeholder/partner issues. Even though all of them were quite far from fulfilling their venture ambitions, never did annoyed, selfish or long-lasting voices interrupt and dominate the $\mathrm{Ba}$. Such voices might have turned the $\mathrm{Ba}$ into a monologue of individual freedom that could cause the entrepreneurs to fail in dialogue or to be reluctant to obligate each other to define a more concrete path to follow. Overall, they defined themselves in borderline dialogue and polyphony, and the drive to become someone and to develop their venture seemed strong. Their way of practicing the polyphonic ideal took into account that voices do not become voices in a Ba until they do something to each other, until they move each other in a dialogue. For example, one entrepreneur said, 'I shall take responsibility for my health to a greater degree... I have learned this today while talking to the others ... It makes me feel good to contribute with my competence in relation to the challenges faced by the others.' 
So where there is friction within the I-Other relation, there is potential for dialogue. The Ba seems to set an ambition of living out an ideology of dialogical relations and of everybody getting a voice and sharing their voice with each other in the process. Consequently, a view of a Ba living on the plane of a polyphonic dialogue where no particular author/entrepreneur holds the 'ultimate semantic authority' (Morson and Emerson 1990, p. 238) seems to sometimes be realised. It could have turned out otherwise, i.e. $\mathrm{Ba}$ as an isolated, individualised and anonymous plane between them that did not leave much space for going beyond the fragile existence of good intentions and a 'good' conversation. Then it could have become the ultimate semantic authority of their existence and a (monological) alibi for being (Bakhtin 1993). This did not seem to be the case, perhaps because all four entrepreneurs are also founders and perhaps it was easier for them to recreate an ideology that got part of its momentum from events of a strongly felt otherness than it would be for people who had not experienced such otherness first hand. Equally important, they had 'tested' and gained trust in each other before in another project.

The four entrepreneurs reported several significant learning experiences and dialogical events/moments, and in light of a 'secure' but challenging $\mathrm{Ba}$, one question might be even more pressing: Why do the data show so many learning experiences and existential spheres and transformations among the entrepreneurs? The many reflections and the learning that the encounter and induced dialogue between the entrepreneurs triggered opened up for several interpretations. One of them is perhaps of a theoretical nature. Here, we will dwell on one interpretation regarding some possible differences between (epistemological) learning and (ontological) dialogue. To differentiate between dialogical events and learning/reflection is not an obvious issue to elaborate upon either in theorising or in empirical analysis. However, we think that there are important insights to be gained from such a differentiation. We propose a difference between subjects and (trans-) Being or between an epistemological and ontological interpretation. In a summary of empirical interpretations, we show that the entrepreneurs as empirical subjects might be paraphrased in a distinct way-'the inter-actions in Ba show a high degree of dialogue, i.e. the entrepreneurs were engaged in the ideas/voices and utterances of each other'. One might get the impression that the words or utterances are 'dialogised' because of mutual engagement. That is to say, the words and utterances might open a new understanding and at the same time show the presence of 'intersubjectivity'. The use of terms such as dialogue, engagement and utterances in an empirical analysis of entrepreneurial reflection and learning is evidence of an 'epistemological fixation'. This is shown when the intersubjectivity presupposes that the subject or entrepreneur exists (at its best) before entering a knowledge-producing inter-subjectivity/ engagement. Compared to entrepreneurs as carriers of trans-being and as representatives for others outside oneself, it is not real (following an ontological interpretation) to frame or see the entrepreneur this way. The entrepreneur is not self-evidently a subject that can be compared to others' status as subjects, but might instead postulate a form of trans-subjectivity (a higher order of co-being), which is not the same as engagement and intersubjective dialogue. In other words, the voices and dialogue exist on a fundamental level prior to the single entrepreneur being understood as an individual. That is to say, the entrepreneur as a subject does not constitute the dialogue, but it is the dialogue that constitutes the entrepreneur. 
To be constituted by dialogue means inheriting other aspects than the 'epistemologised' dialogue. We think that it is important to acknowledge that the dialogue as a phenomenon manifests itself through other lenses than just those of interaction, inter-subjectivity and learning. With this being said, it is obvious that the epistemological implications manifest themselves in Ba interactions. It seems empirically reasonable to interpret the dialogue as a 'learning' interaction when one seeks to dialogise $\mathrm{Ba}$ and the voices of the entrepreneurs. In this way, the empirical focus might shift to emphasising practical learning situations, techniques and activities. If this picture held us captive, we might say that the learning role of dialogue in $\mathrm{Ba}$ is preferred before $\mathrm{Ba}$ in the dialogue. Having this in mind, the value of the practical daily learning situations should not be underestimated.

The empirical material and theoretical perspectives in this paper might serve to contribute to some aspects of the (ontological) question of 'what an organisation really is'. There are different views on how organisational reality should be considered and represented. However, '[o]rganizational representations tend to oscillate between conceiving organizations as objects vs. sets of relations. Neither of these images alone is sufficient to capture organizational functioning' (Tsoukas 1992, p. 441), and we might add that it is not enough to capture the depth of organisational/entrepreneurial being (existence) and becoming (learning). By introducing the concept of $\mathrm{Ba}$, we try to show how organisational functioning is more than representational objects and objectified sets of relations, i.e. that " $\mathrm{Ba}$ is a phenomenological time and space where knowledge, as "a stream of meaning”, emerges' (Nonaka and Toyama 2015, p. 96). Not only is Ba a place for knowledge, but $\mathrm{Ba}$ is also an existential place where entrepreneurs dwell in dialogues and create new meanings through interaction (as shown in empirical descriptions). Entrepreneurs in Ba who are thrown into dialogical border spheres (see page 20) in an unpredictable future (project) might serve to question our understanding of established organisational borders and a functionalistic reality/world.

Here, it is relevant to draw on Heideggerian terminology to shed light on $\mathrm{Ba}$ as a being-in-the-world or (being in) place. In Heidegger's (1962) formulation, it is in our (entrepreneurial) nature to be thrown into existence and to always be ahead of ourselves and to be engaged in the unfolding of not being at home and of being at home. In comparison, Bakhtin (1993) emphasises the dialogical unfolding of projected realities. In the entrepreneur's world, the entrepreneur is at home in Ba and in dialogue. It is possible to talk about the carpenter's world, the entrepreneur's world, where there is an intimacy and familiar use of tools in such a way that the entrepreneur sometimes (in Ba) feels at home or sees housing as being a place.

Perhaps we might see how ontological dialogues or not being at home (not in the right place) is the first experience of entrepreneurial freedom, as a freedom from things and other people (networks, business relations, customers). It is a freedom to begin to become oneself as an entrepreneur. It is the experience of detachment from things, tools and business analysis and from others where one can begin to think freely for oneself as an entrepreneur or as one who is entrepreneurial. This suggests a stronger emphasis on relational being/existence in Ba. In other words, we suppose that being in becoming (learning) also deserves a perspective on becoming in being. Here, the radical point of departure is that $\mathrm{Ba}$ arises in the relational process only when that process/dialogue is present in the experiences and places of any of the entrepreneurs involved. In 
entrepreneurial practice, this is also a question of judging what 'places' we rest on or where we are situated, i.e. how places in Ba might provide strong resistance and the potential of a new dialogical existence and new learning possibilities.

In light of this empirical material, we also propose a theoretical conceptual development. That is to say, the terms $\mathrm{Ba}$ and dialogue might benefit from each other. Nishida (1970) originally framed $\mathrm{Ba}$ as a 'knowledge' place, where new knowledge emerges based on changes of meanings. This framing we might call an epistemic Ba where knowledge emerges. However, Ba might inherit an existential (ontological) place where not only changes of knowledge, learning and reflection occur but also where threshold spheres and changes of being show themselves. Based on the empirical case, we find that both epistemological and ontological aspects of $\mathrm{Ba}$ are present and are important. $\mathrm{Ba}$ is more than (an epistemic) place of interaction, and it is also an existential movement and transformation.

Moreover, entrepreneurial activity at the team or individual level is continuously reinventing new ways of working and thinking but failing to perform routine tasks, which is also at the core of entrepreneurial success (Bledow et al. 2009). All four of the entrepreneurs in this study reported sensitivity and stability in relation to the context for entrepreneurial practice, or more concretely, how the (relatively stable) contingencies (economics, partners, regional/governmental institutions, competitive ventures, networks, etc.) surround and influence their entrepreneurial practice and how potential (radical) innovation processes must be planned and must coexist with many established and routinised processes. This dialogic understanding of entrepreneurial practice sheds light on the process of entrepreneurship as a creative and destructive process, as a process that creates as well as destroys ideas, suggestions and processes. Consequently, entrepreneurial practice is not just about the creation of a 'kingdom' à la Schumpeter (1934), with a sovereign entrepreneur ruling it, but about polyphonic dialogues and interactions undertaken according to the one Ba space created by both the I-Other and borderline existential spheres. Even though this study might have longitudinal aspirations, some of the findings in this paper need to be further tested in a follow-up study in order to be able to say something about the long-term effects of the learning and existential dialogues/experiences that were designed for the four entrepreneurs. This will also respond to the criticism that the lack of longitudinal studies in the field of entrepreneurship constitutes a major methodological drawback of accumulating theory (Sexton 1997; Aldrich and Baker 1997; Summer et al 2001).

\section{Conclusions}

Our study has implications on different levels and for different key stakeholders where three main groups are identified: (1) the entrepreneur him-/herself, (2) the educators (universities and higher education institutions) and (3) private and public institutions aiming to support start-ups and growth-oriented small companies with, for example, financial, organisational, marketing and product-development assistance, all of which are important contributors to the entrepreneur's knowledge reservoir (Rennemo et al. 2017). These organisations are frequently mentioned in the literature as ESOs.

Entrepreneurs who are running small businesses usually have limited possibilities to join learning networks that are able to challenge them with new perspectives and understandings about their company. This is well documented in our study, and all 
four of the entrepreneurs commented upon this in their reflections after the arranged meetings. The entrepreneur needs to put him-/herself into networks that are able to provide support for this demand on learning networks.

Still, from what we have seen in the examples from our data, this might be difficult for the entrepreneur to do on his/her own. They need help, and this study clearly shows the need for more facilitation and training programmes for post-start-up entrepreneurs. We highlight the need for educators and entrepreneurial trainers to have a fuller understanding of what we might call lifelong learning processes situated in temporary Bas. Formal educational programmes directed towards entrepreneurs are certainly important and needed, but such programmes are costly and time consuming. However, we have shown here the important effects of easily arranged and inexpensively facilitated meetings. Two important conditions have been identified for making such meetings successful-(1) the need for a basic level of trust between the entrepreneurs in the dialogue, which in our case was established in the period before the first arranged meeting when the entrepreneurs were involved together in a development and networking programme (women and growth), and (2) professional facilitation from trainers involved. Regarding the last point, we are not talking about rocket science. The ability to encourage and handle a free dialogue between entrepreneurs, some tools for reflections and repetition of meeting structures from time to time seem to be the most important facilitating techniques. The contract between the facilitators/researchers and the entrepreneurs was simple, well presented and agreed upon; the entrepreneurs paid for their travel costs and the researchers/facilitators were allowed to use the videos and written reflections as research data.

The implications for key stakeholders in the entrepreneurs' external knowledge reservoir are in line with those mentioned above. We have no intention of overruling the concrete help entrepreneurs get from ESOs, such as private or public financial and marketing, organisational and product-development advisors. We think, though, that the learning dimensions that can be made possible in dialogues and Ba practices need to be paid more attention to by the same stakeholders, either by themselves or in cooperation with private or public consultants or educational institutions such as universities.

\section{Abbreviations}

ESO: Entrepreneurship support organisations; ZCD: Zone of current development; ZPD: Zone of proximal development

\section{Acknowledgements}

We would like to thank the four women entrepreneurs who took part in this study for letting us present their stories in the way we have done. We are very grateful for your help! Thanks also to our colleague Geir Gran for giving us technical support.

\section{Funding}

This research received no specific grant from any funding agency in the public, commercial or not-for-profit sectors.

Availability of data and materials

The datasets used and/or analysed during the current study are available from the corresponding author on reasonable request.

\section{Authors' contributions}

Each author have contributed equally and consequently have participated sufficiently in the work to take public responsibility for appropriate portions of the content; and agreed to be accountable for all aspects of the work in ensuring that questions related to the accuracy or integrity of any part of the work are appropriately investigated and resolved. 


\section{Publisher's Note}

Springer Nature remains neutral with regard to jurisdictional claims in published maps and institutional affiliations.

Received: 5 October 2018 Accepted: 14 February 2019

Published online: 28 March 2019

\section{References}

Aldrich, H., \& Baker, T. (1997). Blinded by the cites? Has there been progress in the entrepreneurship field? In D. Sexton \& R. Smilor (Eds.), Entrepreneurship (Vol. 2000, pp. 377-400). Chicago: Upstart Publishing Company.

Aldrich H. E. \& Martinez M. A. Many are called, but few are chosen: an evolutionary perspective for the study of entrepreneurship. Entrepreneurship Theory and Practice, 2001;25(4):41-56.

Argyris, C., \& Schön, D. (1978). Organizational learning: a theory of action perspective. Reading: Addison Wesley.

Åsvoll, H., \& Jacobsen, P. J. (2012). A case study: action based entrepreneurship education. How experience problems can be overcome and collaboration problems mitigated. Journal of Entrepreneurship Education, 15. 75-97.

Augier, M., Shariq, S., \& Vendelø, M. (2001). Understanding context: its emergence, transformation and role in tacit knowledge sharing. Journal of Knowledge Management, 5(2):125-136.

Bakhtin, M. (1984). Problems of Dostoevsky's poetics (C. Emerson, trans.). In P. Morris (Ed.), The Bakhtin reader. Selected writings of Bakhtin, Medvedev, Voloshinov (pp. 89-96). London: Edward Arnold.

Bakhtin, M. (1993). In V. Liapunov (Ed.), Toward a philosophy of the act. Austin: Texas University Press.

Bakhtin, M.. \& Volosinov, V. (1929/1994). Marxism and the philosophy of language (L. Jatejka \& I. R. Titunik, trans.). In P. Morris (Ed.), The Bakhtin reader. Selected writings of Bakhtin, Medvedev, Voloshinov (pp. 26-37). London: Edward Arnold.

Bjerke, B. (2005). Förklara eller förstå entreprenörskap? Lund: Studentlitteratur.

Bledow, R., Frese, M., Anderson, N., Erez, M., \& Farr, J. (2009). A dialectic perspective on innovation: conflicting demands, multiple pathways, and ambidexterity. Industrial and Organizational Psychology, 2, 305-337.

Boud, D., Keogh, R., \& Walker, D. (1985). Reflection: turning experience into learning. London: Kogan Page.

Boutaiba, S. (2004). Moment in time. In D. Hjorth \& C. Steyaert (Eds.), Narrative and discursive approaches in entrepreneurship. A second movement in entrepreneurship book (pp. 22-56). Celtenham: Elgar Publishing.

Bruner, J. (1986). Actual minds, possible worlds. Cambridge: Harvard University Press.

Bryman, A., \& Bell, E. (2015). Business research methods (4th ed.). Oxford: Oxford University Press.

Creswell, J. V. (1998), Qualitative inquiry and research design. Choosing among five. Traditions (in italics). Thousand Oaks, CA: Sage.

Cope, J. (2005). Toward a dynamic learning perspective of entrepreneurship. Entrepreneurship Theory and Practice, 29(4), 373-397.

Cope, J., \& Watts, G. (2000). Learning by doing: an exploration of experience, critical incidents and reflection in entrepreneurial learning. International Journal of Entrepreneurial Behaviour and Research, 6(3), 104-124.

Coşgel, M. (1996). Metaphors, stories, and the entrepreneur in economics. History of Political Economy, 28(1), 57-76.

Creplet, F. (2000). The concept of 'Ba': a new path in the study of knowledge in firms. European Journal of Economic and Social Systems, 14(4), 365-379.

Dalborg, C. (2013). Tillväxt i kvinnors företag. In von Friedrichc \& Rennemo (Eds.), Kvinners foretak og foretakende kvinner. Trondheim: Akademika Forlag.

Daunfeldt, S.-O., Halvarsson, D., \& Johansson, D. (2011). Snabbväxande företag: En fördjupad analys av mått och definitioner. Rapport 2011 (p. 27). Östersund: Tillväxtanalys.

De Faoite, D., Henry, C., Johnston, K., \& van der Sijde, P. (2003). Entrepreneurs' attitudes to training and support initiatives: Evidence from Ireland and the Netherlands. Journal of Small Business and Enterprise Development, 11(4), 440-448.

Deakins, D., \& Freel, M. (1998). Entrepreneurial learning and the growth process in SMEs. The Learning Organization, 5(3), 144-155.

Deakins, D., \& Freel, M. (2010). Entrepreneurship and small firms. Maidenhead; Berkshire: McGraw-Hill.

Dobbs, M., \& Hamilton, R. T. (2007). Small business growth: recent evidence and new directions. International Journal of Entrepreneurial Behaviour \& Research, 13, 296-322.

Dubois, A., \& Gadde, L.-E. (2002). The construction industry as a loosely coupled system: productivity and innovation. Construction Management and Economics, 20,621-631.

Emirbayer, M. (1997). Manifesto for a relational sociology. American Journal of Sociology, 103(2), $281-317$.

Fayard, P. (2003). Strategic communities for knowledge creation: a Western proposal for the Japanese concept of Ba. Journal of Knowledge Management, 7, 25-31.

Fleming, D. (2001). Narrative leadership: using the power of stories. Strategy and Leadership, 29(4), 2-16.

Gartner, W. B. (1993). Words lead to deeds: towards an organizational emergence vocabulary. Journal of Business Venturing, 8, $231-240$.

Gartner, W. B., Bird, B. J., \& Starr, J. A. (1992). Acting 'as if: differentiating entrepreneurial from organizational behavior. Entrepreneurship Theory and Practice, 16(3), 13-31.

Gstraunthaler, T., \& Hendry, S. (2011). Entrepreneurial education through action-based learning. The Genesis project. Journal of Entrepreneurship Education, 14, 125-146.

Hamilton, E. (2006). Whose story is it anyway? International Small Business Journal, 24(3), 253-271.

Heidegger, M. (1962). Being and time. New York: Harper \& Row.

Hermans, H. J. M., \& Kempen, H. J. G. (1993). The dialogical self: meaning as movement. San Diego: Academic Press.

Hernes, T. (2014). A process theory of organizing. Oxford: Oxford University Press.

Hills, G. E. (1988). Variations in university entrepreneurship education: an empirical study of an evolving field. Journal of Business Venturing, 3(2), 109-122.

Hindle, K. (2007). Teaching entrepreneurship at university. From the wrong building to the right philosophy. In Fayolle (Ed.) Handbook of research in entrepreneurial education (pp. 104-124). Celtenham: Elgar.

Hjorth, D., Holt, R., \& Steyaert, C. (2015). Entrepreneurship and process studies. International Small Business Journal, 33(6), 599-611. 
Hjorth, D., \& Johannisson, B. (2007). Learning as an entrepreneurial process. In A. Fayolle (Ed.), Handbook of research in entrepreneurship education (pp. 46-66). Celtenham: Elgar.

Hjorth, D., \& Johannisson, B. (2009). Learning as an entrepreneurial process. Revue de l'Entrepreneuriat, 8(2), 57-78.

Hjorth, D., \& Steyaert, C. (2004). Narrative and discursive approaches in entrepreneurship. A second movement in entrepreneurship book. Celtenham: Elgar Publishing.

Holquist, M. (1990). Dialogism. Bakhtin and his world. London: Routledge.

Johansson, A. W. (2004). Narrating the entrepreneur. International Small Business Journal, 22, 273-293.

Kettunen, J. (2011). Innovation pedagogy for universities of applied sciences. Creative Education, 2(1), 56-62.

Lave, J. (1992). Situated learning. Learning in doing: social, cognitive and computational perspectives. Cambridge: Cambridge University Press.

Lave, J., \& Wenger, E. (1991). Situated learning: legitimate peripheral participation. Cambridge: Cambridge University Press.

Lichtenstein, G. A., Lyons, T. S., \& Kutzhanova, N. (2004). Building entrepreneurial communities: The appropriate role of enterprise development activities. Journal of the Community Development Society, 35(1), 5-24.

Linell, P., \& Marková, I. (1993). Acts in discourse: from monological speech acts to dialogical inter-acts. Journal for the Theory of Social Behaviour, 23, 173-195.

Mantere, S., Aula, P., Schildt, H., \& Vaara, E. (2013). Narrative attributions of narrative failure. Journal of Business Venturing, 28(4), 459-479.

Marková, I. (1987). On the interaction of opposites in psychological processes. Journal for the Theory of Social Behavior, $17,279-299$.

Marsick, V. J. (2002). Exploring the many meaning of action learning and ARL. In L. Rohlin et al. (Eds.), Earning while learning. Lund: MiL Publishers/Studentlitteratur.

Mcmullan, W. E., \& Long, W. A. (1987). Entrepreneurship education in the nineties. Journal of Business Venturing, 2(3), $261-275$.

Mezirow, J. (1990). How critical reflection triggers transformative learning. J. Mezirow \& associates (Eds), Fostering critical reflection in adulthood: A guide to transformative and emancipatory learning. (p. 1-20). San Francisco: Jossey-Bass.

Mezirow, J. (1991). Transformative dimensions of adult learning. San Francisco: Jossey-Bass.

Morson, G. \& Emerson, C. (1990). Mikhail Baktin. Creation.of prosaics. Stanford University Press.

Nakamori, Y. (2006). Designing, utilizing and evaluating 'technology creating Ba' in a Japanese scientific research institution. Systems Research and Behavioral Science, 23(3), 3-19.

Nishida, K. (1970). Fundamental problems of philosophy. Tokyo: Sophia University.

Nonaka, I. (1998). The concept of "Ba": Building.foundation for knowledge creation, California Management Review, spring 1998: 40-54.

Nonaka, I., \& Konno, N. (1998). The concept of "Ba": building a foundation for knowledge creation. California Management Review, 40, 40-54.

Nonaka, I. \& Takeuchi, H. (1995). The knowledge creating company. How japanese companies create the dynamics of innovations, New York. Oxford University Press.

Nonaka, I., \& Toyama, R. (2015). The knowledge-creating theory revisited: knowledge creation as a synthesizing process. In J. Edwards (Ed.), The essentials of knowledge management. New York: Palgrave.

Nonaka, I., Toyama, R., \& Konno, N. (2000). SECl, Ba and leadership: a unified model of dynamic knowledge creation. Long Range Planning, 33, 5-34.

Nonaka, I., Von Krogh, G., \& Voelpel, S. (2006). Organizational knowledge creation theory: evolutionary paths and future advances. Organization Studies, 27, 1179-1208.

O'Neil, J., \& Marsick, V. J. (2005). Understanding action learning. New York: AMACOM/American Management Association.

Page West III, G., Gatewood, E. J., \& Shaver, K. G. (2009). Handbook of university-wide entrepreneurship education. UK USA: Edward Elgar.

Peirce, C. S. (1986). Writings of Charles S. Peirce: a chronological edition (Vol. 3, pp. 1872-1878). Bloomington: Indiana University Press.

Politis, D. (2005). The process of entrepreneurial learning: a conceptual framework. Entrepreneurship Theory and Practice, 29(4), 399-424.

Rae, D. (2000). Understanding entrepreneurial learning: a question of how? International Journal of Entrepreneurial Behaviour and Research, 6(3), 145-159.

Rae, D. (2004). Practical theories from entrepreneurs' stories: discursive approaches to entrepreneurial learning. Journal of Small Business and Enterprise Development, 11(2), 195-202.

Rae, D. (2006). Entrepreneurial learning: a conceptual framework for technology-based enterprise. Technology Analysis \& Strategic Management, 18(1), 39-56.

Ray, T., \& Little, S. (2001). Communication and context: collective tacit knowledge and practice in Japan's workplace ba. Creativity and Innovation Management, 10(3), 154-164.

Rennemo, Ø. (2015). Entrepreneurial trainers - the competence mix in action-oriented entrepreneurship development programs. Journal of Entrepreneurship Education, 18(2), 135-150.

Rennemo, Ø., Widding, L. Ø., \& Bogren, M. (2017). Business growth through intentional and non-intentional network processes. Journal of Small Businesses and Enterprise Development, 24(2), 242-260.

Schumpeter, J. A. (1934). The theory of economic development. An inquiry into profits, capital, credit, interest, and the business cycle. Cambridge: Harvard University Press.

Sexton, D. L. (1997). Entrepreneurship research needs and issues. In D. Sexton \& R. Smilor (Eds.), Entrepreneurship 2000 (pp. 401-408). Chicago: Upstart Publishing Company.

Shane, S., \& Sarasvathy, S. (2000). The promise of entrepreneurship as a field of research. Academy of Management Review, 25(1), 217-226.

Shane, S., \& Venkataraman, S. (2000). The promise of entrepreneurship as a field of research. Academy of Management Review, $25,217-226$.

Sørheim, R., \& Rasmussen, E. A. (2006). Action-based entrepreneurship education. Technovation, 26(2), 185-194.

Stake, R. E. (1995). The art of case study research. London: Sage Publications. 
Steyaert, C. (1995). Perpetuating entrepreneurship through dialogue. Doctoral dissertation. Leuven: Kathdike Universiteit Leuven. Steyaert, C. (1997). Human, all too human resource management-constructing the subject in HRM (p. 28). Copenhagen: Papers in Organization.

Steyaert, C. (1998). A qualitative methodology for process studies of entrepreneurship: creating local knowledge through stories. International Studies of Management and Organisation, 27(3), 13-33.

Steyaert, C. \& Hjorth, D. (2003). Entrepreneurship beyond (a new) economy. In C. Steyaert \& D. Hjorth (Eds.), New movements in entrepreneurship (pp. 286-303). Cheltenham: Elgar.

Steyaert, C., \& Katz, J. (2004). Reclaiming the space of entrepreneurship in society: geographical, discursive and social dimensions. Entrepreneurship \& Regional Development, 16(3), 179-196.

Sullivan, R. (2000). Entrepreneurial learning and mentoring. International Journal of Entrepreneurial Behaviour and Research, 6(3), 160-175

Summer P, Low M, \& Wright M. (2001). Editors' introduction: low and MacMillan ten years on: achievements and future directions for entrepreneurship research. Entrepreneurship Theory and Practice, 25-23.

Tsoukas, H. (1992). Ways of seeing: topographic and network representations in organization theory. Systems Practice, 5, 441-456.

Tsoukas, H., \& Chia, R. (2002). On organizational becoming: rethinking organizational change. Organization Science, 13, 568-582.

Van de Ven, A. H., \& Poole, M. S. (1995). Explaining development and change in organizations. Academy of Managamenet. The Academy of Management Review, 20(3), 510-540.

Von Friedrichs, Y., \& Rennemo, Ø. (2013). Kvinners foretak og foretakende kvinner. Trondheim: Akademika Forlag.

Vygotsky, L. S. (1978). Mind in society: the development of higher psychological process. Cambridge: Harvard University Press. Wenger, E. (1998). Communities of practice: learning as a social system. Systems Thinker, 9(5), 2-3.

Wenger, E., McDermott, R., \& Snyder, W. (2002). Cultivating communities of practice: a guide to managing knowledge. Cambridge: Harvard Business School Press.

Wertsch, J. V. (1991). Voices of the mind: a sociocultural approach to mediated action. Cambridge: Harvard University Press.

Submit your manuscript to a SpringerOpen ${ }^{\odot}$ journal and benefit from:

- Convenient online submission

- Rigorous peer review

- Open access: articles freely available online

High visibility within the field

Retaining the copyright to your article

Submit your next manuscript at $\boldsymbol{\nabla}$ springeropen.com 